\title{
The neuroimmune-endocrine axis: pathophysiological implications for the central nervous system cytokines and hypothalamus-pituitary-adrenal hormone dynamics
}

J. Licinio and

P. Frost
Department of Psychiatry and Neuropsychiatric Institute,

School of Medicine, University of California, Los Angeles, CA, USA

\section{Correspondence}

J. Licinio

UCLA Gonda Center 3357A

695 Charles Young Dr. So.

Los Angeles, CA 90095-1761

USA

Fax: + 1-310-825-6407

E-mail: licinio@ ucla.edu

Presented at the First

International Meeting on Adrenal

Disease: Basic and Clinical

Aspects, Ribeirão Preto, SP, Brazil,

August 31-September 2, 1999.

Received December 20, 1999

Accepted August 9, 2000
Abstract

Cytokines are molecules that were initially discovered in the immune system as mediators of communication between various types of immune cells. However, it soon became evident that cytokines exert profound effects on key functions of the central nervous system, such as food intake, fever, neuroendocrine regulation, long-term potentiation, and behavior. In the 80's and 90's our group and others discovered that the genes encoding various cytokines and their receptors are expressed in vascular, glial, and neuronal structures of the adult brain. Most cytokines act through cell surface receptors that have one transmembrane domain and which transduce a signal through the JAK/STAT pathway. Of particular physiological and pathophysiological relevance is the fact that cytokines are potent regulators of hypothalamic neuropeptidergic systems that maintain neuroendocrine homeostasis and which regulate the body's response to stress. The mechanisms by which cytokine signaling affects the function of stress-related neuroendocrine systems are reviewed in this article.

\section{Key words}

- Central nervous system

- Cytokines

- Immune system

- Neuroendocrine regulation

- Fever

- Food intake

\section{Introduction}

In 1716 the Académie des Sciences de Bordeaux offered a prize for an answer to the question 'Quel est l'usage des glandes surrenales?" In light of the several conflicting and fantastic answers, Montesquieu, the judge (who at that time was 29 years old), decided not to award the prize. His closing comment was "Le hazard fera peut-être quelquejour ce que tous les soins n'ont su faire" (Perhaps some day chance will reveal what all of this work was unable to do) (1).
In the following 283 years the combined work of anatomists, physiologists, pathophysiologists, surgeons, geneticists, and molecular biologists has led to enormous progress in our understanding of the biology of the adrenal glands. For example, the crucial role of cortisol in the adaptation to stress, metabolism, immune responses and survival are now well known. New frontiers of research include the regulation of adrenal function at the local and systemic levels in health and disease. Considerable genetic, molecular, and cellular research has been conducted 
on the adrenal gland. However, the functioning of a complex system is the product of multiple molecular and cellular events. Thus, while a mere examination of function will not unravel the mechanisms of regulation, detailed work with specific cellular and molecular models will also not uncover the dynamics of functioning and malfunctioning in the intact organism. Consequently, a balanced program of research should examine fundamental mechanisms at the molecular and cellular level. This review will cover some recent advances on specific modulators that are highly related to and integrated with adrenal function. Specifically, we will discuss the role of central nervous system (CNS) cytokines in the neuroimmune-endocrine axis.

The adrenal gland is the anchor of the hypothalamus, pituitary, and adrenal gland neuroendocrine axis (HPA) and its role as the link between the neuroendocrine and immune system has been well characterized. The HPA axis is activated by inflammatory cytokines (e.g., IL-1ß, TNF- $\alpha$, IL-6) produced at the site of peripheral infection or inflammation by activated lymphocytes and macrophages. These cytokines enter the systemic circulation, and through mechanisms that remain unclear, upregulate the expression of corticotropin-releasing hormone $(\mathrm{CRH})$ and adrenocorticotropic hormone (ACTH) from the paraventricular nucleus $(\mathrm{PVN})$ of the hypothalamus and the anterior pituitary, respectively. The adrenal gland responds to ACTH by upregulating glucocorticoids, which ultimately downregulate the immune response. Recent evidence has added to our understanding of this regulatory network, especially since many immunomodulatory cytokines are also expressed in cells within the CNS. This suggests that other novel immune-neuroendocrine signaling and regulatory pathways may exist, and that immuno- and neuromodulatory cytokines may be major components of this system.
Cytokines were initially discovered as chemical messengers integrating the various elements of the immune response. Perhaps even more interesting is the increasing body of evidence supporting a role for cytokines as modulators of CNS function and behavior. This has exciting implications in future understanding and treatment of psychiatric disorders, such as major depression, bipolar disorder, and schizophrenia, whose etiology has been linked to dysfunction of the immune system. Thus, understanding how cytokines are regulated and function in the CNS may lead to new insights in brain disorders, ultimately contributing to the development of novel strategies to treat these diseases. However, as most cytokines and chemokines can be expressed in the nervous system, it becomes impractical to study or review all of them in the same setting. Thus, this discussion will be focused on the family of interleukin (IL) 1-related molecules.

\section{The IL-1 system: components and expression in the CNS}

The signaling networks of most cytokines are characterized by both redundancy and pleotropism, and IL-1 is no exception. For example, IL-1 bioactivity is characterized by the action of several unique ligands (IL-1 $\alpha$, IL-1ß) $(2,3)$, and the IL-1 receptor antagonist (IL-1ra) $(4,5)$. Two receptors have been identified, IL-1 receptor type I (IL1RI), which has a long intracellular domain (6), and IL-1 receptor type II (IL-1RII), which has a truncated intracellular domain, does not transduce a signal, functions as a decoy for bioactive IL-1, and is upregulated by anti-inflammatory cytokines (e.g., IL-13) and steroids $(7,8)$. Finally, a number of soluble receptors (9), receptor-related proteins (10), receptor-like molecules (11), an IL-1 accessory protein (12), and autoantibodies are involved in IL-1 signaling. In addition, a regulatory enzyme (IL-1ß converting enzyme or caspase 1) is responsible for cleaving the 
pro-IL- $1 \beta$ to its active form (for a review, see 13). IL-1ra, the first pure endogenous receptor antagonist to be discovered, is a unique component of this system.

Cytokines target the brain through a number of mechanisms, including a) disruption of the blood-brain barrier, b) penetration in the brain through circumventricular organs (these sites in the brain have capillaries with open junctions and abundant fenestrations), c) de novo synthesis in the CNS, and d) direct signaling of the brain through peripheral nerves. It is still not known which of these mechanisms, either alone or in concert, are involved in specific pathophysiological situations (8).

IL-1B, in response to various physiological and pathological stimuli, is produced by many different cells in the CNS, including neurons, microglia, endothelial cells and astrocytes. Furthermore, administration of exogenous IL-1ß produces "stress like" changes in behavior, food intake, monoamine neurotransmitters, HPA axis activity and immune function (14-21). IL-1ß, a product of the inflammatory response, is a major upregulator of hypothalamic CRH secretion $(22,23)$. Moreover, IL-1ß has been reported to be a potent regulator of the serotonin transporter gene (24). These findings are important, since the serotonin transporter is a primary target for antidepressants, cocaine, and amphetamines. Furthermore, modulation of the human serotonin transporter gene by a physiologically occurring cytokine has not been described previously.

The first experiments that localized cytokine gene expression in the rat brain were conducted during the 80 's. IL-1B was localized in the human hypothalamus by Saper's group (25) and localization of the mRNAs encoding the signal-transducing IL-1 receptor in the mouse brain and IL-1ra in the rat brain soon followed (26-28). The functional IL-1RI mRNA and several other components of the IL-1 system were localized in the rat brain using in situ histochemistry hybridization (29-33). Given the important role of IL-1 bioactivity in regulation of HPA function and behavior, several investigators have conducted studies to address key questions related to the role of IL-1 ra in the brain.

\section{Neuroendocrine-immune effects of cytokines on CNS function}

IL-1ra is a naturally occurring pure endogenous antagonist of IL-1 actions, and both transcription and translation of this cytokine occur in the brain. In contrast to the actions of IL-1ß, exogenous IL-1ra administration in the brain is neuroprotective in animal models of stroke (31). Thus, we and others have hypothesized that IL-1ra may act as an endogenous neuroprotective factor in the brain. Studies of middle cerebral artery occlusion demonstrated that cerebral expression of IL-1ra is rapidly induced by focal cerebral ischemia in rats, and passive immunoneutralization of IL-1ra markedly enhanced damage (32). Therefore, endogenous IL-1ra can be upregulated by acute neurodegenerative events and its expression is sufficient to limit the amount of neuronal loss or damage. These findings have been independently replicated using pre-ischemic conditioning, as well as gene transfer methods $(33,34)$. It is likely that low (physiological) levels of IL-1 allow the maintenance of neuronal plasticity in the adult brain, while excessive and sustained production of IL-1, which occurs rapidly following brain injury, dramatically impairs both neuronal and nonneuronal cell functions and survival.

The sensitivity of specific neurons to IL1-mediated inflammatory insults may depend upon the level of constitutive IL-1ra expression and both the rate and extent of its synthesis following damage to the CNS. Understanding the mechanisms of IL-1ra and IL-1 13 expression in the brain following injury may be of therapeutic benefit for the treatment of neurodegenerative disorders. The search for endogenous neuroprotective 
molecules represents a promising therapeutic strategy for neurodegeneration. These findings are of relevance to the biology of the medical consequences of major depression. For example, Sheline et al. $(35,36)$ showed that atrophy of the hippocampus and amygdala in major depression was positively correlated with the effects of glucocorticoids or CRH.

In work conducted to show the role of $\mathrm{CRH}$ in acute neurodegeneration, it was shown that CRH mRNA levels were elevated 2.6-fold within $1 \mathrm{~h}$ after middle cerebral artery occlusion, when compared to shamoperated animals. Furthermore, the induction of CRH mRNA ipsilaterally in the amygdala, following ischemia, was qualitatively different from that of sham-operated animals (37). These findings, when interpreted in the light of previous studies showing neuroprotection by $\mathrm{CRH}$ antagonists in animal models of acute ischemia $(38,39)$, led to the concept that high levels of endogenous CRH may contribute to neurotoxicity. Strijbos et al. (39) showed that neuroprotection caused by $\mathrm{CRH}$ antagonism is not due to decreased cortisol levels since RU-486, a type II glucocorticoid receptor antagonist, or dexamethasone, does not affect focal cerebral ischemia. The possibility that CRH may have a role in acute neuronal loss in ischemia raises two important issues. First, it substantiates the potential therapeutic benefit of CRH antagonists in treating stroke. Secondly, abnormalities in the CRH levels in the CNS are associated with several human diseases, including major depression (40-42), anorexia nervosa (43) and Alzheimer's disease (44). It remains to be determined whether these disorders are related to changes in central CRH levels and/or cytokine expression. However, the evidence that overexpression of CRH/IL-1 may be associated with neurotoxicity provides an additional rationale to investigate drugs affecting $\mathrm{CRH}$ function in the treatment of these disorders. The hypothesis that high CRH/IL-1ra or IL-1B/IL-1ra ratios lead to neuronal loss should be tested in post mortem studies.

\section{Functional regulation of the neuroimmune-endocrine axis during inflammation}

\section{How is IL-1 bioactivity regulated in the brain during inflammation?}

The CNS responds to systemic inflammation with pronounced IL- $1 \beta$ gene expression and limited IL-1ra, IL-10, and IL-13 gene expression (45). This pattern occurs throughout the CNS, including the subfornical organ, pineal gland, neurohypophysis, and hypothalamus. In contrast, the anterior pituitary expresses limited IL- $1 ß$ gene activity but markedly upregulates the secreted isoform of IL-1ra (sIL-1ra) mRNA. These findings are concordant with reports on IL$1 \beta$ and IL-1ra bioactivity following peripheral lipopolysaccharide (LPS) treatment $(46,47)$. The concept that inflammatory cytokines acting within the brain to regulate key elements of the CNS response to peripheral inflammation has been substantiated by the findings that CNS functions can be attenuated or in some cases abolished by central administration of IL-1ra $(21,48)$. For example, the induction of CRH gene expression in the PVN in response to peripheral LPS administration can be abolished by the central, but not peripheral, administration of IL-1ra, suggesting that the actions of IL- $1 ß$ within the brain are required for $\mathrm{CRH}$ mRNA induction during peripheral inflammation (48).

The signal-transducing IL-1RI has not been identified in brain regions where IL- $1 \beta$ modulates activity. Therefore, it is difficult to explain how central IL-1ß might mediate CNS effects at the cellular and molecular levels. In response to peripheral inflammation, peripheral cytokines such as IL-1ß are synthesized and may circulate in the blood stream. This is followed by the synthesis of $\mathrm{IL}-1 \beta$ in key areas of the brain, such as the 
PVN. Paradoxically, IL-1 receptors do not seem to be present in those areas. It is possible that novel IL-1 receptors exist in the brain. However, in spite of considerable effort by several groups, such receptors have not been identified or cloned. Secondly, since inflammation downregulates IL-1 receptors, it is possible that the lack of evidence of IL1RI expression in the PVN in previous studies was due to previous infection or inflammation; however, this is unlikely in light of previous studies that have rigorously controlled for inflammation (49). Finally, it is possible that IL-1ß, acting in areas that send inputs to the PVN, areas that are adjacent to the PVN, or at the level of brain vasculature (50) within the PVN, might cause the generation of other informational molecules, such as prostanoids $(49,51)$ or nitric oxide (NO) (52). This may result in the indirect modulation of IL-1ß-mediated effects on PVN function as discussed in more detail below.

Our current hypothesis is that the central (CNS) and peripheral (immune) cytokine compartments are integrated but differentially regulated. The central manifestations of peripheral immune responses to infection and inflammation are mediated by IL- $1 \beta$ synthesized in the brain during the context of limited counter-regulation of IL-1ra. This is in contrast to the peripheral regulation of systemic inflammation where it is advantageous to counter-regulate IL- $1 ß$ action at the periphery, thus limiting the inflammatory response. On the other hand, actions of IL-1 in the brain cause sickness behavior, leading to sleep, decreased search for food, inhibition of reproduction, and suppression of locomotion and exploration, thereby facilitating recovery and reducing the likelihood of confrontation with predators.

\section{Does IL-1ß-induced iNOS contribute to brain-immune interactions?}

IL-1ß has been shown to induce iNOS
mRNA and NO production in vascular and brain cells in vitro (53) and to induce iNOS in vivo. During systemic inflammation, iNOS gene expression was accompanied by the production of $\mathrm{NO}$ metabolites in brain parenchyma and cerebrospinal fluid (CSF). The spillover of NO metabolites, such as nitrites, into the CSF has the potential to be a diagnostic marker for systemic inflammation and sepsis. The effects of IL-1ß on iNOS induction and NO production is dependent upon the local ratio of IL-1ß and of cytokines that inhibit IL-1 action (e.g. IL1ra). Therefore, high IL-13/IL-1ra mRNA ratios in the brain during systemic inflammation could explain the pathophysiologically significant iNOS gene transcription and bioactivity in the brain described during systemic inflammation. Neuroanatomical studies revealed that early in the course of systemic inflammation iNOS mRNA in vascular, glial, and neuronal structures of the rat brain is profoundly upregulated $(50,54)$. The pituitary, the pineal, PVN and the arcuate nucleus strongly upregulated iNOS mRNA during inflammation. Interestingly, it has been proposed that infections throughout life result in iNOS expression, resulting in turn in high levels of NO production, and leading to increased cytotoxicity, whose lifetime cumulative effect contributes to the aging process (55).

\section{Is there a systemic, endocrine role for CNS cytokines?}

The PVN-synthesized IL-1ß may not act directly in the brain, but rather may be secreted into hypophyseal portal blood as a hypothalamic cytokine/neurohormone that regulates pituitary function. During inflammation, IL-1ß in the circulation directly stimulates pituitary cells to secrete ACTH, $\mathrm{LH}, \mathrm{GH}$, and TSH, and inhibits the secretion of prolactin (56). These pituitary effects have led Bernton and colleagues (56) to propose that IL-1, acting directly at several sites that 
include the pituitary gland, may be an important regulator of the metabolic adaptations to infectious stressors. The pituitary is particularly responsive to IL- $1 \beta$ during stress or inflammation because CRH induces the expression of IL-1RI receptors in the pituitary gland (57), thereby increasing the sensitivity of the pituitary to IL- $1 B$. The anterior pituitary expresses moderate levels of IL-1ß, but very high levels of mRNA for the secreted IL-1ra. The pituitary secretion of sIL-1ra may represent a novel systemic hormonal anti-inflammatory mechanism elicited either during systemic inflammation through the anterior pituitary or from multiple central sources, such as the PVN, arcuate nucleus, median eminence, posterior pituitary, and the anterior pituitary itself (45).

Intracerebroventricular administration of IL-1ß has been demonstrated to activate the brain and/or its supporting structures to release IL-6 directly into the blood independent of peripheral sympathetic activity or central mobilization of CRH (58). The direct CNS-mediated secretion of IL-6, and possibly other cytokines, has been postulated to be a pathway of neuroimmunomodulation (59) in much the same way that the hormonal cascade released from the HPA axis modulates peripheral endocrine effects. Thus, the relationship between peripheral and central cytokines is such that peripheral cytokines, originating from immune cells, affect the functioning of the brain, and central cytokines secreted by the brain feedback to peripheral immune function.

\section{New directions for clinical research on the physiological regulation of adrenal function in humans}

New endocrine sampling techniques, with highly intensive sampling intervals have the potential to fully characterize human HPA function in health and disease. Such studies, which are being conducted by our group and others, can accomplish the following: a) characterize both the long-term functioning of the HPA axis, and b) detail the minute-tominute regulation of ACTH:cortisol ratio, thereby quantifying the dynamics of the adrenal responsiveness to ACTH; c) analyze the level of complexity and the architecture of circulating cortisol and ACTH concentrations as an index of functional integrity of the HPA axis; d) examine the dynamics of point-to-point incremental variation of hormone concentrations in health and disease.

\section{Conclusions}

The HPA axis has been extensively studied. While fundamental molecular mechanisms help us identify the various elements of HPA regulation, integrative studies allow us to dissect the complexities of HPA functioning in health and disease. Progress in genetics, molecular biology, integrative physiology, and clinical research should be integrated so that a full and clinically useful understanding of HPA function and its relationship to immune mediators can be achieved.

\section{References}

1. Nelson DH (1988). Pituitary-adrenal system. In: McCann SM (Editor), Endocrinology - People and Ideas. American Physiological Society, Bethesda, MD, 87-115.

2. March CJ, Mosley B, Larsen A, Cerretti DP, Braedt G, Price V, Gillis S, Henney CS, Kronheim SR, Grabstein K, Conlon PJ , Hopp TP \& Cosman D (1985). Cloning, sequence and expression of two distinct human interleukin-1 complementary DNAs. Nature, 315: 641-647.

3. Lomedico PT, Gubler $U$, Hellmann $C P$, Dukovich M, Giri J G, Pan YCE, Collier K, Semionow R, Chua AO \& Mizel SB (1984). Cloning and expression of murine interleukin-1 cDNA in Escherichia coli. Nature, 312: 458-462.

4. Hannum CH, Wilcox CJ , Arend WP, J oslin
FG, Dripps DJ , Heimdal PL, Armes LG, Sommer A, Eisenberg SP \& Thompson RC (1990). Interleukin-1 receptor antagonist activity of a human interleukin-1 inhibitor. Nature, 343: 336-340.

5. Eisenberg SP, Evans RJ, Arend WP, Verderber E, Brewer MT, Hannum CH \& Thompson RC (1990). Primary structure and functional expression from comple- 
mentary DNA of a human interleukin-1 receptor antagonist. Nature, 343: 341346.

6. Sims J E, March CJ, Cosman D, Widmer $M B, M a c D o n a l d ~ H R, ~ M C M$ ahan CJ, Grubin CE, Wignall J M, J ackson J L, Call $S M$, Friend D, Alpert AR, Gillis S, Urdal DL \& Dower SK (1988). cDNA expression cloning of the IL-1 receptor, a member of the immunoglobulin superfamily. Science, 241: 585-589.

7. Colotta F, Re F, Muzio M, Polentanutti N, Minty A, Caput D, Ferrara P \& Mantovani A (1994). Interleukin-13 induces expression and release of interleukin-1 decoy receptor in human polymorphonuclear cells. J ournal of Biological Chemistry, 269: 12403-12406.

8. Licinio J (1997). Central nervous system cytokines and their relevance for neurotoxicity and apoptosis. J ournal of Neural Transmission, 49 (Suppl): 169-175.

9. Symons J A, Eastgate JA \& Duff GW (1991). Purification and characterization of a novel soluble receptor for interleukin 1. J oumal of Experimental Medicine, 174: 1251-1254.

10. Lovenberg TW, Crowe PD, Liu CL, Chalmers DT, Liu XJ, Liaw C, Clevenger W, Oltersdorf T, DeSouza EB \& Maki RA (1996). Cloning of a cDNA encoding a novel interleukin-1 receptor related protein (IL 1R-rp2). J ournal of Neuroimmunology, 70: 113-122.

11. Pamet P, Garka KE, Bonnert TP, Dower SK \& Sims JE (1996). IL-IRrp is a novel receptor-like molecule similar to the type I interleukin-1 receptor and its homologues T1/ST2 and IL-1R ACP. J oumal of Biological Chemistry, 271: 3967-3970.

12. Liu C, Chalmers D, Maki R \& De SE (1996). Rat homolog of mouse interleukin-1 receptor accessory protein: cloning, localization and modulation studies. J ournal of Neuroimmunology, 66: 41-48.

13. Dinarello CA (1996). Biologic basis for interleukin-1 in disease. Blood, 87: 20952147.

14. Connor TJ , Song C, Leonard BE, Merali Z \& Anisman H (1998). An assessment of the effects of central interleukin-1beta, -2 , -6 , and tumor necrosis factor-alpha administration on some behavioural, neurochemical, endocrine and immune parameters in the rat (in process citation). Neuroscience, 84: 923-933.

15. Weiss J M, Sundar SK, Becker KJ \& Cierpial MA (1989). Behavioral and neural influences on cellular immune responses: effects of stress and interleukin-1. J ournal of Clinical Psychiatry, 50 (Suppl S): 43-
53 (discussion 54-55).

16. Bluthe RM, Sparber S \& Dantzer R (1992). Modulation of the behavioural effects of interleukin-1 in mice by nitric oxide. NeuroReport, 3: 207-209.

17. Bluthe RM, Dantzer R \& Kelley KW (1991). Interleukin-1 mediates behavioural but not metabolic effects of tumor necrosis factor alpha in mice. European J ournal of Pharmacology, 209: 281-283.

18. Bluthe RM, Crestani F, Kelley KW \& Dantzer R (1992). Mechanisms of the behavioral effects of interleukin 1. Role of prostaglandins and CRF. Annals of the New York Academy of Sciences, 650: 268-275.

19. Bluthe RM, Michaud B, Kelley KW \& Dantzer R (1996). Vagotomy attenuates behavioural effects of interleukin-1 injected peripherally but not centrally. NeuroReport, 7: 1485-1488.

20. Bluthé RM, Beaudu C, Kelley KW \& Dantzer R (1995). Differential effects of IL-1ra on sickness behavior and weight loss induced by IL-1 in rats. Brain Research, 677: 171-176.

21. Linthorst AC, Flachskamm C, Muller PP, Holsboer F \& Reul J M (1995). Effect of bacterial endotoxin and interleukin-1 beta on hippocampal serotonergic neurotransmission, behavioral activity, and free corticosterone levels: an in vivo microdialysis study. J ournal of Neuroscience, 15: 29202934.

22. Sapolsky R, Rivier C, Yamamoto G, Plotsky P \& Vale W (1987). Interleukin-1 stimulates the secretion of hypothalamic corticotropin releasing factor. Science, 238: 522-524.

23. Berkenbosch $F$, van Oers J, del Rey A, Tilders F \& Besedovsky H (1987). Corticotropin-releasing factor-producing neurons in the rat activated by interleukin-1. Science, 238: 524-536.

24. Ramamoorthy S, Ramamoorthy JD, Prasad PD, Bhat GK, Mahesh VB, Leibach FH \& Ganapathy V (1995). Regulation of the human serotonin transporter by interleukin-1 beta. Biochemical and Biophysical Research Communications, 216: 560567.

25. Breder CD, Dinarello CA \& Saper CB (1988). Interleukin-1 immunoreactive innervation of the human hypothalamus. Science, 240: 321-324.

26. Licinio J, Wong ML \& Gold PW (1991). Localization of interleukin-1 receptor antagonist mRNA in rat brain. Endocrinology, 129: 562-564.

27. Cunningham ETJ, Wada E, Carter DB, Tracey DE, Battey JF \& De Souza EB
(1992). In situ histochemical localization of type I interleukin-1 receptor messenger RNA in the central nervous system, pituitary, and adrenal gland of the mouse. J ournal of Neuroscience, 12: 1101-1114.

28. Gabellec MM, Griffais R, Fillion G \& Haour $F$ (1995). Expression of interleukin 1 alpha, interleukin 1 beta and interleukin 1 receptor antagonist mRNA in mouse brain: regulation by bacterial lipopolysaccharide (LPS) treatment. Brain Research Molecular Brain Research, 31: 122-130.

29. Yabuuchi K, Minami $M$, Katsumata $S$ \& Satoh M (1994). Localization of type I interleukin-1 receptor mRNA in the rat brain. Brain Research Molecular Brain Research, 27: 27-36.

30. Wong ML \& Licinio J (1994). Localization of interleukin 1 type I receptor mRNA in rat brain. Neuroimmunomodulation, 1 : 110-115.

31. Relton J K \& Rothwell NJ (1992). Interleukin-1 receptor antagonist inhibits ischaemic and excitotoxic neuronal damage in the rat. Brain Research Bulletin, 29: 243246.

32. Loddick SA, Wong $M L$, Bongiomo $P B$, Gold PW, Licinio J \& Rothwell NJ (1997). Endogenous interleukin-1 receptor antagonist is neuroprotective. Biochemical and Biophysical Research Communications, 234: 211-215.

33. Barone EJ, Yager DR, Pozez AL, Olutoye OO, Crossland MC, Diegelmann RF \& Cohen IK (1998). Interleukin-lalpha and collagenase activity are elevated in chronic wounds [see comments]. Plastic and Reconstructive Surgery, 102: 10231027 (discussion 8-9).

34. Yang GY, Liu XH, Kadoya C, Zhao YJ , Mao Y, Davidson BL \& Betz AL (1998). Attenuation of ischemic inflammatory response in mouse brain using an adenoviral vector to induce overexpression of interleukin-1 receptor antagonist. J ournal of Cerebral Blood Flow and Metabolism, 18: 840-847.

35. Sheline YI (1996). Hippocampal atrophy in major depression: a result of depressioninduced neurotoxicity. Molecular Psychiatry, 1: 298-299.

36. Sheline YI, Gado MH \& Price J L (1998). Amygdala core nuclei volumes are decreased in recurrent major depression [published erratum appears in NeuroReport (1998), 9: 2436]. NeuroReport, 9: 2023-2028.

37. Wong $M L$, Loddick $S A$, Bongiorno PB Gold PW, Rothwell NJ \& Licinio J (1995). Focal cerebral ischemia induces $\mathrm{CRH}$ mRNA in rat cerebral cortex and amygdala. NeuroReport, 6: 1785-1788. 
38. Lyons MK, Anderson RE \& Meyer FB (1991). Corticotropin-releasing factor antagonist reduces ischemic hippocampal neuronal injury. Brain Research, 545: 339342.

39. Strijbos PJ, Relton JK \& Rothwell NJ (1994). Corticotropin-releasing factor antagonist inhibits neuronal damage induced by focal cerebral ischaemia or activation of NMDA receptors in the rat brain. Brain Research, 656: 405-408.

40. Nemeroff CB, Widerlov E, Bissette G, Walleus $\mathrm{H}$, Karlsson I, Eklund $\mathrm{K}$, Kilts $\mathrm{CD}$, Loosen PT \& Vale W (1984). Elevated concentrations of CSF corticotropin-releasing factor-like immunoreactivity in depressed patients. Science, 226: 1342-1344.

41. Gold PW, Loriaux DL, Roy A, Kling MA, Calabrese JR, Kellner CH, Nieman LK, Post RM, Pickar D, Gallucci W, Avgerinos $P$, Paul S, Oldfield EH, Cutler GB \& Chrousos GP (1986). Responses to corticotropin-releasing hormone in the hypercortisolism of depression and Cushing's disease. Pathophysiologic and diagnostic implications. New England J ournal of Medicine, 314: 1329-1335.

42. Nemeroff CB, Owens MJ, Bissette G, Andorn AC \& Stanley M (1988). Reduced corticotropin releasing factor binding sites in the frontal cortex of suicide victims. Archives of General Psychiatry, 45: 577. 579.

43. Gold PW, Gwirtsman H, Avgerinos PC, Nieman LK, Gallucci WT, Kaye W, J imerson D, Ebert M, Rittmaster R, Loriaux DL \& Chrousos GP (1986). Abnormal hypothalamic-pituitary-adrenal function in anorexia nervosa. Pathophysiologic mechanisms in underweight and weightcorrected patients. New England J oumal of Medicine, 314: 1335-1342.

44. De Souza EB, Whitehouse PJ , Kuhar MJ , Price DL \& Vale WW (1986). Reciprocal changes in corticotropin-releasing-factor (CRF)-like immunoreactivity and CRF receptors in cerebral cortex of Alzheimer's disease. Nature, 319: 593-595.

45. Wong $\mathrm{ML}$, Bongiorno $\mathrm{PB}$, Rettori $\mathrm{V}$, McCann SM \& Licinio J (1997). Interleukin (IL) 1beta, IL-1 receptor antagonist, IL10 , and IL-13 gene expression in the central nervous system and anterior pituitary during systemic inflammation: pathophysiological implications. Proceedings of the National Academy of Sciences, USA, 94: 227-232.

46. Quan N, Sundar SK \& Weiss J M (1994). Induction of interleukin-1 in various brain regions after peripheral and central injections of lipopolysaccharide. J ournal of Neuroimmunology, 49: 125-134.

47. Weiss J M, Quan N \& Sundar SK (1994). Widespread activation and consequences of interleukin-1 in the brain. Annals of the New York Academy of Sciences, 741: 338-357.

48. Kakucska I, Qi Y, Clark BD \& Lechan RM (1993). Endotoxin-induced corticotropinreleasing hormone gene expression in the hypothalamic paraventricular nucleus is mediated centrally by interleukin-1. Endocrinology, 133: 815-821.

49. Ericsson A, Liu C, Hart RP \& Sawchenko PE (1995). Type 1 interleukin-1 receptor in the rat brain: distribution, regulation, and relationship to sites of IL-1-induced cellular activation. J oumal of Comparative Neurology, 361: 681-698.

50. Wong $M L$, Rettori $\mathrm{V}$, Al-Shekhlee $A$, Bongiomo PB, Canteros G, McCann SM, Gold PW \& Licinio J (1996). Inducible nitric oxide synthase gene expression in the brain during systemic inflammation. Nature Medicine, 2: 581-584.

51. Scammell TE, Griffin J D, Elmquist J K \& Saper CB (1998). Microinjection of a cyclooxygenase inhibitor into the anteroven- tral preoptic region attenuates LPS fever. American J ournal of Physiology, 274: R783-R789.

52. Scammell TE, Elmquist JK \& Saper CB (1996). Inhibition of nitric oxide synthase produces hypothermia and depresses lipopolysaccharide fever. American J ournal of Physiology, 271: R333-R338.

53. Romero LI, Tatro J B, Field J A \& Reichlin S (1996). Roles of IL-1 and TNF-alpha in endotoxin-induced activation of nitric oxide synthase in cultured rat brain cells. American J ournal of Physiology, 270: R326R332.

54. Licinio J, Prolo P, McCann SM \& Wong ML (1999). Brain iNOS: current understanding and clinical implications. Molecular Medicine Today, 5: 225-232.

55. McCann SM, Licinio J , Wong ML, Yu WH, Karanth S \& Rettorri V (1998). The nitric oxide hypothesis of aging. Experimental Gerontology, 33: 813-826.

56. Bernton EW, Beach J E, Holaday JW Smallridge RC \& Fein HG (1987). Release of multiple hormones by a direct action of interleukin-1 on pituitary cells. Science, 238: 519-521.

57. Laye $S$, Parnet $P$, Goujon E \& Dantzer R (1994). Peripheral administration of lipopolysaccharide induces the expression of cytokine transcripts in the brain and pituitary of mice. Brain Research Molecular Brain Research, 27: 157-162.

58. Reichlin S (1993). Neuroendocrine-immune interactions. New England J ournal of Medicine, 329: 1246-1253.

59. Romero LI, Kakucska I, Lechan RM \& Reichlin S (1996). Interleukin-6 (IL-6) is secreted from the brain after intracerebroventricular injection of IL-1 beta in rats. American J ournal of Physiology, 270: R518-R524. 